\title{
Strength Properties of Concrete by Replacing Coarse Aggregate by Gabbro Rocks
}

\author{
Mahadeva C K \\ Assistant professor, Department of civil engineering \\ GMIT, Bharatinagara \\ Mandya, India
}

\begin{abstract}
Solid structure is comprised of cement, aggregate and water. In building development the aggregates normally utilized are limestone, in this way the determination of aggregate should to be in the major circumstance. To convey a good quality and excellent cement the materials utilized should be in promise to standard precise. A great deal of materials could be utilized as an admixture or even as a basic part of cement; the point of this examination is to utilize the Gabbro rock as a coarse aggregate in concrete. The pre-owned Gabbro in study is gotten from squander dark rock (as it's privately named). Results demonstrated as an increment in compressive strength. The extent of study remembers the examination for the quality, holding. The fundamental goal of the undertaking is to think about the properties of lime stone and a gabbro identified with quality and its properties. The test conducted for gabbro rocks are flakiness index, elongation index, specific gravity, water absorption test and compressive strength of concrete. Using gabbro rocks concrete higher compressive strength and its properties of concrete.
\end{abstract}

Keywords: Coarse Aggregate, Compressive strength, fine aggregate, gabbro concrete.

\section{INTRODUCTION}

Nowadays, as the field of civil engineering have become so innovative hence providing economic constructions and good strength. Use of Igneous rock aggregates in concrete mixes is to develop their physical properties by the properties of Gabbro rock. To get high strength and good workability gabbro rocks are completely added to the concrete mix in. By the usage of such igneous rock the experiment is carried out till the desired properties are obtained. Since concrete is the most significant part in auxiliary components, the total substance should be in a type of good quality for basic purposes. Concrete is comprised of aggregate, concrete and water. Through this mix of materials, three - quarter of the blend is administered by aggregate. The aggregate itself is arranged as fine and coarse aggregate.

In this study, the scope of research will be focused on the use of coarse aggregate using Gabbro rock material. Before further discussion, it shall be better to have knowledge and clear understanding about the gabbro rock material and its properties and performances. Before further discussion, it shall be better to have knowledge and clear understanding about the gabbro rock material and its properties and performances.
Table 1: Classification of natural aggregates according to rock type (BS 812: Part 1: 1975)

\begin{tabular}{|c|c|c|c|}
\hline \multirow{2}{*}{$\begin{array}{l}\text { Sl } \\
\text { no }\end{array}$} & \multicolumn{3}{|c|}{ Classification of natural aggregate } \\
\hline & Basalt Group & Flinte Group & Gabbro group \\
\hline 1 & $\begin{array}{l}\text { Andesite } \\
\text { Basalt } \\
\text { Basic porphyrites } \\
\text { Diabase } \\
\text { Dolerites of all } \\
\text { kinds } \\
\text { including theralite } \\
\text { and } \\
\text { Teschenite. } \\
\text { Epidiorite } \\
\text { Lamprophyre } \\
\text { Quartz-dolerite } \\
\text { Spilite }\end{array}$ & $\begin{array}{l}\text { Chert } \\
\text { Flint }\end{array}$ & $\begin{array}{c}\text { Basic diorite } \\
\text { Basic Gneiss } \\
\text { Gabbro } \\
\text { Hornblende-rock } \\
\text { Norite } \\
\text { Peridotite } \\
\text { Picrite } \\
\text { Serpentinite }\end{array}$ \\
\hline 2 & Granite Group & $\begin{array}{l}\text { Gritstone Group } \\
\quad \text { (including } \\
\text { fragmental } \\
\text { volcanic rocks) }\end{array}$ & Hornfels group \\
\hline & $\begin{array}{l}\text { Gneiss } \\
\text { Granite } \\
\text { Granodiorite } \\
\text { Granulite } \\
\text { Pegmatite } \\
\text { Quartz-diorite } \\
\text { Syenite }\end{array}$ & $\begin{array}{l}\text { Arkose } \\
\text { Greywacke } \\
\text { Grit } \\
\text { Sandstone } \\
\text { Tuff }\end{array}$ & $\begin{array}{c}\text { Contact-altered rocks } \\
\text { of all } \\
\text { kinds except marble. }\end{array}$ \\
\hline 3 & Limestone Group & Porphyry Group & Quartzite Group \\
\hline & $\begin{array}{l}\text { Dolomite } \\
\text { Limestone } \\
\text { Marble } \\
\text { Schist Group } \\
\text { Phyllite } \\
\text { Schist Slate } \\
\text { All severely } \\
\text { sheared rocks. }\end{array}$ & $\begin{array}{c}\text { Aplite } \\
\text { Dacite } \\
\text { Felsite } \\
\text { Granophyre } \\
\text { Keratophyre } \\
\text { Microgranite }\end{array}$ & $\begin{array}{c}\text { Ganister } \\
\text { Quarzitic sandstones } \\
\text { Re-crystallized } \\
\text { quartzite }\end{array}$ \\
\hline
\end{tabular}

\section{MATERIALS AND METHODOLOGY}

\section{Cement \\ 2. Fine Aggregate \\ 3. Coarse Aggregate \\ 4. Water \\ 5. Gabbro Aggregate}

Sampling of cubes for test

1. Clean the mounds and apply oil.

2 . Fill the concrete in the moulds in layers approximately 5 cm thick.

3. Compact each layer with not less than 35 strokes per layer using a tamping rod (steel bar $16 \mathrm{~mm}$ diameter and $60 \mathrm{~cm}$ long, bullet pointed at lower end). 


\section{REGION OF GABBRO ROCK AVAILABILITY IN INDIA:}

1. Gabbro rock an area of about $5,00,000$ sq.km. covers large part of Maharashtra.

2. Karnataka about 31,500 sq.km. covering Bidar, Belgaum, Bijapur, and Gulbarga Districts.

3. Chamarajanagara.

4. Gujarat.

5. Hyderabad. [1]

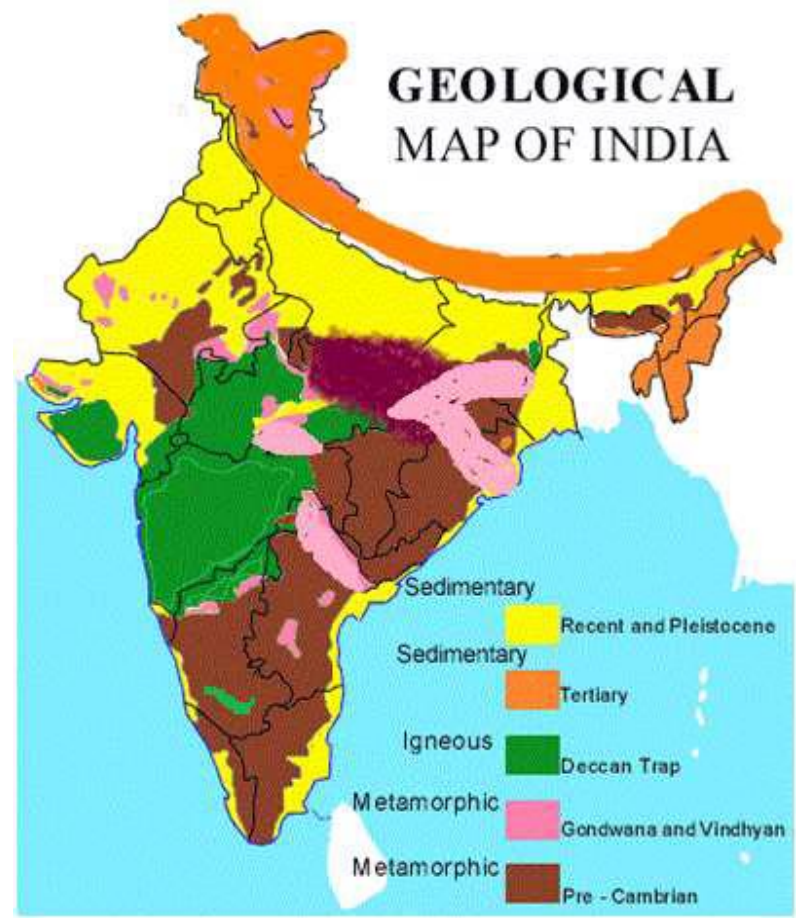

Fig 1: Geological map shows the gabbro rocks

To prove the specification of gabbro aggregate we are conducted flakiness and elongation test. Bonding between aggregate and cement paste depends on the aggregate surface. Since the rough surface requires more bonding than the smooth surface, the texture of aggregate to be tested should comply with the requirement of standard specification.

\section{Energy Dispersive X-ray Spectroscopy (EDS)}

EDS can be utilized to locate the synthetic of materials down to a spot size of a couple of microns, and to make component creation maps over an a lot more extensive raster zone. Together, these capacities give principal compositional data to a wide assortment of materials. An EDS finder contains a precious stone that ingests the vitality of approaching $\mathrm{x}$ beams by ionization, yielding free electrons in the gem that become conductive and produce an electrical charge predisposition.

\section{Precautions for test}

The water for curing should be tested every 7 days and the temperature of water must be at $27+-2^{0} \mathrm{C}$.

\section{LABORATORY TEST}

a. Sieve analysis $\mathbf{4 . 7 9}$ (F.A)

b. Specific gravity $\mathbf{2 . 7 6}$ (F.A)

c. Bulking of Sand $35.86 \%$

d. Sieve analysis $\mathbf{4 . 3 7}$ - fineness modulus

e. Standard consistency of cement $-34 \%$

f. Setting time of cement - initial - $\mathbf{3 5} \mathbf{~ m i n}$.

Setting time of cement -Final - $\mathbf{1 0}$ hrs.

g. Fineness of cement $-6 \%$

h. Impact text $-10.99 \%$

\section{CONCRETE TESTS}

Flakiness and elongation -E index - $\mathbf{4 3 . 6 8 \%}$

a. Slump test $-125 \mathrm{~mm}$

b. Compaction factor test -0.984

\section{GABBRO ROCK TESTS}

a. specific gravity -2.62

b. sieve analysis -2.01

c. Flakiness and elongation index $-\mathrm{F}$ index $-\mathbf{1 4 . 5 6} \%$

Flakiness and elongation index $-\mathrm{E}$ index $-\mathbf{5 0 . 6 5} \%$

\section{A-7 MIX PROPORTIONS}

Cement $=383.16 \mathrm{~kg} / \mathrm{m} 3$

Water $=191.58$ Litres

Fine aggregate $=731.4 \mathrm{~kg} / \mathrm{m} 3$.

Coarse aggregate $=1084.68 \mathrm{~kg} / \mathrm{m} 3$.

Gabbro aggregate $=1265.46 \mathrm{~kg} / \mathrm{m} 3$.

\section{RESULTS OF EDS TEST}

A typical EDS spectrum is portrayed as a plot of $\mathrm{x}$-ray counts vs. energy (in keV). Energy peaks correspond to the various elements in the sample. Generally they are narrow and readily resolved, but many elements yield multiple peaks. For example, iron commonly shows strong $\mathrm{K} \alpha$ and $\mathrm{K} \beta$ peaks. Elements in low abundance will generate $\mathrm{x}$-ray peaks that may not be resolvable from the background radiation.

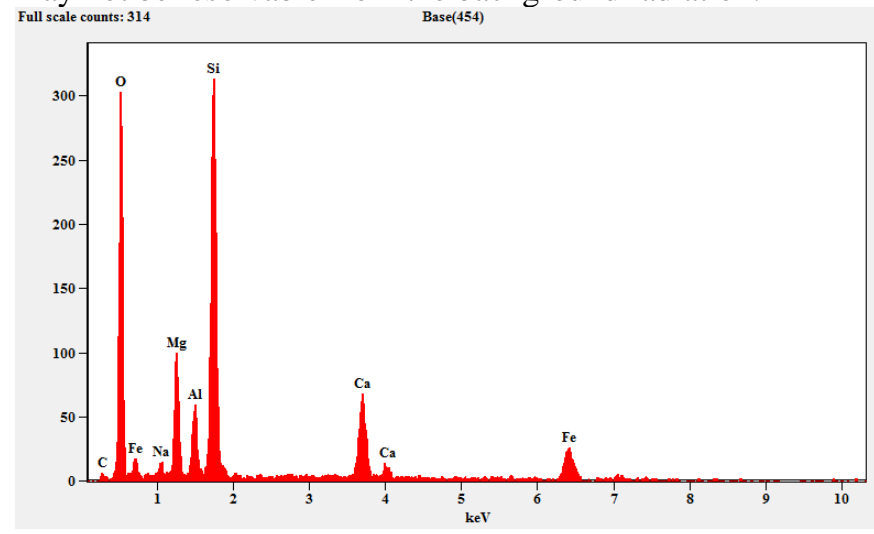


PROCEDURE FOR CONCRETE CUBE TEST

1. After curing specimen is taken out from curing tank and wipe out cube and clean well.

2. Measure the dimension of the specimen nearest to $0.1 \mathrm{~mm}$.

3. To remove the dust from compression or universal testing machine.

4. Test specimens are placed on the testing machine opposite to load direction and test is conducted as per Indian standard code.

5. Specimen is placed centrally on the specimen.

6. Apply the load gradually on the test specimen and note down the readings and calculate the strength of the cube.

7. Record the maximum load and note down the readings and find the usual features.

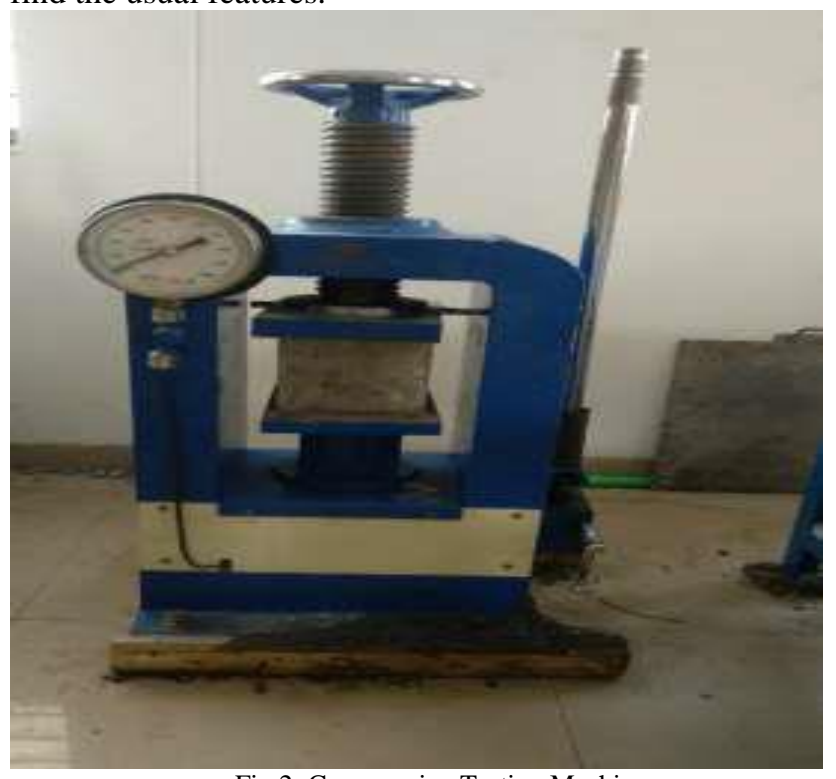

Fig 2: Compressive Testing Machine

\section{RESULTS AND DISCUSSION}

Table2: Chemical Composition of Gabbro Aggregate

\begin{tabular}{|c|c|c|}
\hline SI No & Compound & $\begin{array}{c}\text { Percentage } \\
\text { present }\end{array}$ \\
\hline 1 & Silicon di-oxide & 48 \\
\hline 2 & Aluminum Oxide & 14.4 \\
\hline 3 & Iron oxide & 15.1 \\
\hline 4 & Calcium oxide & 6.18 \\
\hline 5 & Magnesium oxide & 5.95 \\
\hline 6 & Sodium oxide & 4.05 \\
\hline 7 & Potassium oxide & 2.29 \\
\hline 8 & Titanium oxide & 2.29 \\
\hline 9 & Otherwise & 1.74 \\
\hline
\end{tabular}

Table 3: Compressive strength of concrete at various ages

\begin{tabular}{|c|c|c|}
\hline SI No & Age (days) & Strength (\%) \\
\hline 1 & 1 & 16 \\
\hline 2 & 3 & 40 \\
\hline 3 & 7 & 65 \\
\hline 4 & 14 & 90 \\
\hline 5 & 28 & 99 \\
\hline
\end{tabular}

Table 4: Compressive strength test conducted

\begin{tabular}{|c|c|c|c|c|c|}
\hline $\begin{array}{c}\mathrm{Sl} \\
\mathrm{No}\end{array}$ & $\begin{array}{c}\text { proportioni } \\
\text { ng of } \\
\text { material }\end{array}$ & \multicolumn{2}{|c|}{ Load in $\mathrm{KN}$} & $\begin{array}{l}\text { Compressive } \\
\text { strength in } \\
\mathrm{N} / \mathrm{mm}^{2}\end{array}$ & $\begin{array}{c}\text { Avg } \\
\text { compressive } \\
\text { strength in } \\
\mathrm{n} / \mathrm{mm} 2\end{array}$ \\
\hline \multicolumn{6}{|c|}{ Lime stone aggregate } \\
\hline \multirow{2}{*}{1} & \multirow{2}{*}{$1: 1.9: 2.8$} & \multirow{2}{*}{7} & 302.1 & 13.43 & \multirow{2}{*}{16.42} \\
\hline & & & 437.1 & 19.43 & \\
\hline \multirow{2}{*}{2} & \multirow{2}{*}{$1: 1.9: 2.8$} & \multirow{2}{*}{14} & 458.08 & 20.35 & \multirow{2}{*}{20.84} \\
\hline & & & 480.02 & 21.33 & \\
\hline \multirow{2}{*}{3} & \multirow{2}{*}{$1: 1.9: 2.8$} & \multirow{2}{*}{28} & 483.9 & 21.51 & \multirow{2}{*}{21.65} \\
\hline & & & 490.43 & 21.79 & \\
\hline \multicolumn{6}{|c|}{ Gabbro aggregate } \\
\hline \multirow{2}{*}{1} & \multirow{2}{*}{$1: 1.9: 3.3$} & \multirow{2}{*}{7} & 430.08 & 19.14 & \multirow{2}{*}{20.5} \\
\hline & & & 492.02 & 21.86 & \\
\hline \multirow{2}{*}{2} & \multirow{2}{*}{ 1:1.9:3.3 } & \multirow{2}{*}{14} & 593.41 & 26.37 & \multirow{2}{*}{26.47} \\
\hline & & & 598.02 & 26.57 & \\
\hline \multirow{2}{*}{3} & \multirow{2}{*}{$1: 1.9: 3.3$} & \multirow{2}{*}{28} & 785 & 34.88 & \multirow{2}{*}{35.66} \\
\hline & & & 820 & 36.44 & \\
\hline
\end{tabular}

Table 5: Quantitative Results for: Base (454)

\begin{tabular}{|c|c|c|c|}
\hline Element & Weight in \% & $\begin{array}{c}\text { Weight of \% } \\
\text { Error }\end{array}$ & Atom \% \\
\hline $\mathrm{CK}$ & 5.42 & 1.13 & 9.28 \\
\hline $\mathrm{OK}$ & 47.49 & 1.27 & 61.05 \\
\hline $\mathrm{Na} \mathrm{K}$ & 0.66 & 0.35 & 0.59 \\
\hline $\mathrm{Mg} \mathrm{K}$ & 6.08 & 0.42 & 5.14 \\
\hline $\mathrm{Al} \mathrm{K}$ & 3.56 & 0.24 & 2.72 \\
\hline $\mathrm{Si} \mathrm{K}$ & 18.11 & 0.45 & 13.26 \\
\hline $\mathrm{Si} \mathrm{L}$ & - & - & - \\
\hline $\mathrm{Ca} \mathrm{K}$ & 7.49 & 0.48 & 3.84 \\
\hline $\mathrm{Ca} \mathrm{L}$ & - & - & - \\
\hline $\mathrm{Fe} \mathrm{K}$ & 11.19 & 0.76 & 4.12 \\
\hline $\mathrm{Fe} \mathrm{L}$ & - & - & - \\
\hline Total & $\mathbf{1 0 0}$ & - & $\mathbf{1 0 0}$ \\
\hline
\end{tabular}

Table 6: Compressive strength test conducted

\begin{tabular}{|c|c|c|c|c|}
\hline $\begin{array}{c}\text { Sl } \\
\text { NO }\end{array}$ & $\begin{array}{c}\text { Test } \\
\text { Conducted }\end{array}$ & $\begin{array}{c}\text { Lime stone } \\
\text { Aggregate }\end{array}$ & Gabbro & IS code \\
\hline 1 & S G & 2.61 & 2.62 & $383-1970$ \\
\hline 2 & Sieve analysis & 4.37 & 2.01 & $383-1970$ \\
\hline 3 & Impact Test & 10.99 & 13.99 & $2386-1963$ \\
\hline 4 & $\begin{array}{c}\text { Compression } \\
\text { Test }\end{array}$ & 0.92 & 0.987 & $5515-1983$ \\
\hline 5 & Loss angle & 55.44 & 59.56 & $2386-1963$ \\
\hline 6 & Flakiness & 11.62 & 14.56 & $2386-1963$ \\
\hline 7 & Elongation & 43.68 & 50.65 & $2386-1963$ \\
\hline 8 & $\begin{array}{c}\text { Compression } \\
\text { strength } \\
(\mathrm{N} / \mathrm{mm} 2)\end{array}$ & & & \\
\hline & 7 days & 16.42 & 20.5 & \multirow{3}{*}{ 516-1959 } \\
\hline & 14 days & 20.84 & 26.47 & \\
\hline & 28 days & 21.56 & 35.66 & \\
\hline
\end{tabular}

\section{CONCLUSION}

As gabbro rocks is a normally accessible volcanic stone, one of the most solid and scratch obstruction material having dark/dark shading. The compound structure of gabbro contains a few liquefied minerals together framing extremely hard rock, it contains quartz, chromium, nickel, cobalt, gold, silver, platinum and iron.

1. They can be utilized as high quality solid aggregates in the concrete mix.

2. The need of this task examination is to utilize gabbro as coarse aggregate in study, since the gabbro is costly, the utilization of waste gabbro from nearby markets structures lessen the general expense of development. 
3. When in contact with different synthetic compounds they give no substance responses that may harm wellbeing on the earth.

4. So it is natural genial material. Subsequently, the gabbro rocks can be utilized as looking for structures, clearing, and deck and improvement purposes.

\section{REFERENCES}

[1] https://en.wikipedia.org/wiki/gabbro "Gabbro", Wikipedia, the free encyclopedia, page last edited on 6 November, 2017.

[2] www.Rocks.comparenature.com/en/granite-vs-gabbro/comparison-114-0. "compare

[3] rocks", copyright 2015-2018, A softUvista.

[4] http://www.ucl.ac.uk/earth.sciences/impact/rocks/igneous/gabbro. Earth sciences-

[5] Gabbro university college, London, 2018.

[6] http://study.com/academy/lesson/gabbro-uese-facts.html"Gabbro: uses and facts", 2018.

[7] WWW.SOFTSCHOOLS.COM.Gabbrohttp://www.softschools.com/fac ts/rocks/gabbro-facts.

[8] www.matweb.com/search/datasheettext.aspx?bassnum=bmin04 ,"Gabbro Mechanical and Physical properties “, 2018.

[9] https://serc.carleton.edu/research_education/geochemsheets/eds.html. "Geochemical Instrumentation and Analysis.

[10] IS383, Indian Standards Specifications for Coarse and fine Aggregates from Natural Sources for Concrete", 2002.

[11] IS2386-1963 (Part-IV), Indian Standards Specifications for Method of test for Aggregate for Concrete.

[12] IS5515-1983, Indian Standards Specification for specification for compacting apparatus.

[13] IS2386-1963 (Part I), Indian Standards Specification for Method of test for Aggregate for Concrete.

[14] IS516-1959, Indian Standards Specification for Method of tests for concrete. 